\title{
Swedish vineyards: a utopia?
}

\author{
This article was published in the following Dove Press journal: \\ International Journal of Wine Research \\ 18 July 2013 \\ Number of times this article has been viewed
}

\begin{abstract}
Anna Mårtensson'
Thord Karlsson ${ }^{2}$ Jan-Gunnar Gustafsson ${ }^{3}$

'Department of Soil and Environment, ${ }^{2}$ Department of Economics, Swedish University of Agricultural Sciences, Uppsala, Sweden; ${ }^{3}$ Bio Evaluation AB, Uppsala, Sweden
\end{abstract}

\begin{abstract}
As there is an increasing interest for setting up vineyards and wineries in Sweden, a cost analysis is becoming necessary. In this study, we assessed the potential for wine production in Sweden. The estimated annual costs varied from $€ 15.1 /$ per L for production of $1800 \mathrm{~L}$ wine per ha to $€ 41.9$ for $525 \mathrm{~L}$ per ha. For an annual production of $1800 \mathrm{~L}$ per ha potentially achieved in an established vineyard, the capital requirement is $€ 730,000$. It would take 6 years for the investment to be paid off if the wine was sold for $€ 37.5$ per L. The high production costs mean that the only viable option for success is to orientate production towards the exclusive upper segment.
\end{abstract}

Keywords: cold climate conditions, wine production costs, wine quality

\section{Introduction}

Interest in winemaking, including wine cultivation and wine production, is increasing in Sweden. Sweden currently has permission to grow vines commercially on an area of 100 ha. As long as this is not exceeded, Sweden is not affected by the European Union (EU) ban on new planting. Current yields are around 400-600 L of wine per ha, which can be compared with yield levels in, for example, Australia, with 30,000 L per ha, or in Europe, where average yields are around 8000-10,000 L per ha. The low yield is mainly due to the Swedish climate, as growth conditions are restricted by low temperatures, but also the young age of the vineyards. On the basis of mean yields reported for other fruits and berries and grower's experience, it should be possible to achieve yields in the order of $3000 \mathrm{~L}$ per ha in more mature vineyards but with a large variation depending on prevailing seasonal weather conditions. ${ }^{1}$

People who have already started growing and marketing their own wine in Sweden do not have a traditional farm background, but come from real estate, information technology, or similarly profitable sectors in society, which generally means that they are financially independent of their wine production. Their business concept for wine cultivation and wine production has usually not been explicit from the beginning, but has been more of a hobby. These facts may hamper the success of establishing a wine production business in Sweden. Many entrepreneurs are interested in starting a vineyard and winery, but are not aware of the investment needed in capital and knowledge.

To start a wine production unit, including the chain from cultivation to selling a product, investments in the form of money and expertise are needed. Expertise can be obtained through trial and error, but this is time-consuming and costly. An established farmer with a crop production background has the advantage of possessing
Correspondence: Anna Mårtensson

Department of Soil and Environment, Swedish University of Agricultural

Sciences, Box 70I4, SE 75007 Uppsala, Sweden

Tel +46 I8 671222

Fax +46 18672795

Email anna.martensson@slu.se which permits unrestricted noncommercial use, provided the original work is properly cited. 
land, premises, and some equipment that can be used in wine cultivation. However, most of the equipment needed, particularly as regards wine production, is specialized and must be bought or rented. Regardless of the reason for setting up a vineyard (main source of income or hobby), large investments are essential, but hard facts relating to the costs and need for expertise are lacking. Therefore, this paper presents an example of estimated costs for a Swedish vineyard and winery.

\section{Material and methods \\ Calculation of production costs}

The production costs for cultivating and producing wine on a farm were calculated on the basis of cost estimates related to establishment (ie, purchasing land, vines, machinery for land preparation), subsequent annual soil and crop management measures, grape harvesting, wine making, and buildings. All these costs arise before any grapes are harvested and can be subdivided into fixed and variable costs. Finally, costs for marketing and storage were included in the calculation. The cost of labor was set at $€ 17.0$ per hour, which is the rate paid to Swedish farm workers. The size of the wine yard was defined as 5 ha, which is considered realistic in the current situation, where four commercial Swedish producers cover an approximate total of 25 ha.

From these estimations, the profitability of a Swedish vineyard was calculated. Here different annual yields were considered, but with the vineyard's own starting capital of $20 \%$. The interest rate was set at $7 \%$ on borrowed capital and different retail prices for the wine were considered.

\section{Results}

Table 1 shows the estimated cost picture for a Swedish vineyard of 5 ha, assuming that the vineyard does not produce any wine in the first 3 years. Depending on the volume of wine produced, the cost for producing a liter of wine varied between $€ 15.1$ and $€ 41.9$. The investment costs amounted to $€ 534,000$ (Table 1).

Table 2 shows the estimated profitability for the same 5 ha Swedish vineyard with different levels of output and different retail prices for the wine. The volume of wine produced per year proved to be the most important parameter in achieving profitability. The minimum production in order to break even was in the order of $450 \mathrm{~L}$ of wine per ha. With production of $1800 \mathrm{~L}$ per ha, a retail price of around $€ 20.0$ per liter ( $€ 15.0$ per bottle) was needed to break even.

\section{Discussion}

Start-up costs for a wine cultivation and production unit include investment and operational costs, which can be estimated, but also expertise, which is more difficult to estimate as it includes many scales and areas, not least knowing the regulations relating to production. ${ }^{2}$ However, those who succeed in overcoming all the obstacles to getting established can

Table I Estimated costs for a Swedish vineyard of 5 ha. The vineyard produces no wine in the first 3 years

\begin{tabular}{|c|c|c|c|c|}
\hline Investments & $\begin{array}{l}\text { Costs for production of } \\
525 \mathrm{~L} \text { wine/ha and year }\end{array}$ & $\begin{array}{l}\text { Output of } 525 \mathrm{~L} \\
\text { wine/ha and year, } \\
€ / L\end{array}$ & $\begin{array}{l}\text { Output of } 1050 \mathrm{~L} \\
\text { wine/ha and year, } \\
\epsilon / L\end{array}$ & $\begin{array}{l}\text { Output of } 1800 \mathrm{~L} \\
\text { wine/ha and year, } \\
€ / L\end{array}$ \\
\hline Land & 25,000 & & & \\
\hline Establishment, year I & 176,000 & & & \\
\hline Maintenance, years $2-3$ & 133,000 & & & \\
\hline Buildings & 50,000 & & & \\
\hline Machinery for cropping & 50,000 & & & \\
\hline Equipment for winemaking & 100,000 & & & \\
\hline Total investment & 534,000 & & & \\
\hline \multicolumn{5}{|l|}{ Cropping } \\
\hline Fixed costs & 33,750 & 9.6 & 4.8 & 2.8 \\
\hline Variable costs & 67,500 & 19.3 & 16.7 & 6.9 \\
\hline Total cropping & 101,250 & 28.9 & 15.5 & 9.7 \\
\hline \multicolumn{5}{|l|}{ Winemaking } \\
\hline Fixed costs & 11,340 & 3.2 & 1.7 & 9.0 \\
\hline Variable costs & 21,300 & 6.1 & 3.5 & 2.5 \\
\hline Total winemaking & 32,640 & 9.3 & 5.2 & 3.4 \\
\hline Marketing & 10,000 & 2.9 & 2.1 & 1.7 \\
\hline Storage costs & 2660 & 0.8 & 0.4 & 0.3 \\
\hline $\begin{array}{l}\text { Total cropping, winemaking, marketing, } \\
\text { storage costs }\end{array}$ & 146,550 & 41.9 & 23.5 & 15.1 \\
\hline
\end{tabular}




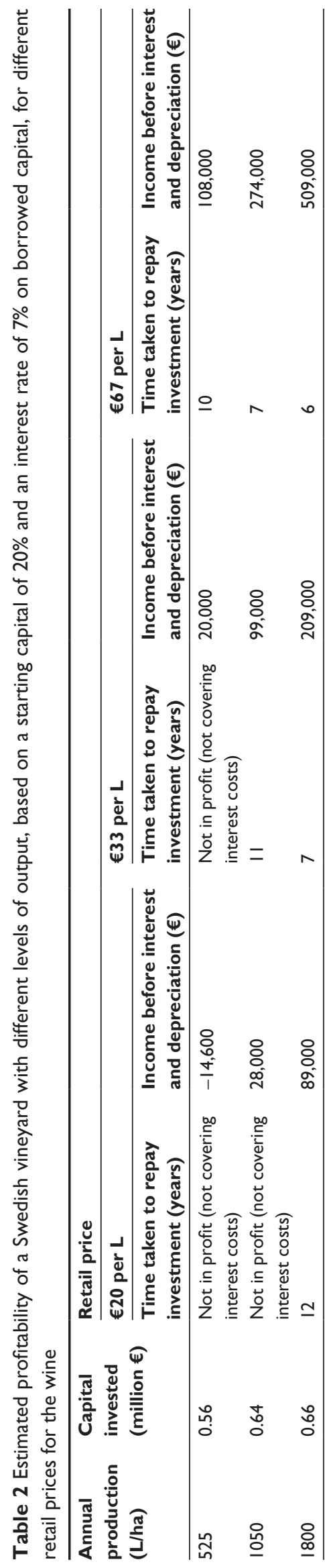

earn money from their business. A farmer wanting to include wine production in their farm business has the advantage of having land and farm equipment that can be used for growing the wine. There may be vacant farmhouses that could be used for the winery. However, most of the equipment needed for making wine is specialist equipment that has to be purchased, or rented if possible.

Before start-up, all production permits must be arranged and distribution channels initiated. The distribution channels available in Sweden are limited and include regional outlets operated by the national Swedish monopoly retailer for alcoholic drinks (Systembolaget). The small lot list that Systembolaget provides for consumers upon request includes exports and local restaurants. Systembolaget's standard range contains no Swedish-grown wines due to the small volumes produced. Any consumer wishing to buy Swedish wine in a region where it is not offered in local Systembolaget retail outlets has to order it from the small lot list, which requires planning and organization. Vineyards are currently not permitted to sell directly to consumers, but a change in the regulations is impending. ${ }^{3}$ For export, good contacts and marketing abroad are necessary, which restricts this option, while EU legislation also contributes to restricting this course of action. ${ }^{4}$

During the vineyard establishment years, it must be borne in mind that no harvests can be taken. In addition, more labor time is needed during the establishment phase than when the vineyard is established. In the following years, training and thinning the vines and harvesting require great labor inputs. ${ }^{5,6}$ Other factors to consider are location and design of the vineyard (whether roads, water, electricity, etc are available and whether there is space for further expansion); whether there already are established vineyards in the area, ie, if the region has a reputation as a wine region, which is very unlikely to be the case in Sweden; whether the land is situated in an environmentally protected area; and the cultivation history of the land.

Unfortunately there has been no classification of Swedish soils with respect to suitability for wine cultivation, which, as pointed out by Maschmedt et al, is a key factor for success. ${ }^{7}$ Furthermore, if the benefits of large-scale production are desired, large areas of vines may have to be planted and managed, so the current permitted area for Swedish vineyards may become a problem. However, a small wine business may be more competitive on the market if supplying an exclusive upper sector, as shown by Beverland. ${ }^{8}$ This is also shown by the increasing numbers of smaller vineyards in the USA concentrating on producing wines in the upper 
market segment. ${ }^{9}$ On the other hand, the stability and willingness to pay in the upper market price sector may be questioned. ${ }^{10}$ In addition, the long-term planning of the business should consider the specific problems relating to growth of small businesses. ${ }^{11}$

When vine planting in Sweden, the rows cannot be placed as closely together as is possible further south in Europe, but the vine density within rows can be the same. This is because the sun is lower in the sky in Sweden and therefore greater spacing is needed to prevent shading by neighboring rows. This gives fewer plants per unit area and, as a consequence, smaller volumes of harvested grapes. The predominantly cold climate also gives fewer and smaller grapes per vine. The median lower temperature during the growing season reduces the amount of grapes per plant although this can be a benefit, resulting in higher quality of the grapes..$^{12}$ Based on statistics available on the production of berries and fruits in Sweden, the potential quantities of wine per hectare are in the range of 1500-2500 L (2000-3300 bottles), but a newly planted wine yard yields less. In the example given here, three different yield levels were chosen based on harvest data obtained from growers (Tables 1 and 2). ${ }^{1}$

At present, 10 black grape varieties and 19 green grape varieties are permitted in Sweden. ${ }^{13}$ The choice of grape variety is a strategic decision and should be considered carefully as wine consumers are conservative and prefer well-known grape varieties. ${ }^{14}$ It is therefore questionable whether it is worth growing cold-tolerant hybrids, which do not produce flavorsome wines. The cost of stocks depend on variety and origin, but it is important to use high quality vines to ensure the success of the vineyard. ${ }^{15}$ In Sweden it is possible to use nongrafted stocks, which add appropriately to the quality and image. In the present example, the cost of plant material was based on a single vine costing $€ 2.0$ and 3000 vines being needed per ha (Table 1). In a later phase, new vines can be produced within the vineyard through cuttings. The present example estimated that the vineyard required 750 poles per ha, at a cost of $€ 9.5$ each. Tying-in vines was expected to require 9000 meters of wire per ha at a cost of $€ 900$. It was also estimated that planting took 15 minutes per plant costing $€ 12,600$ in labor. The vineyard was presumed to be fenced off with 400 meters of $120 \mathrm{~cm}$ high sheep fencing to avoid damage from wild animals such as elk and roe deer, at a cost of $€ 1.02$ per meter. In addition, 150 fence posts at $€ 6.0$ were needed for the fencing, with an erection time of 100 hours.

As regards the cost of land, the type of land suitable for wine cultivation is currently not particularly in demand in Sweden, but the price is expected to rise with an increasing interest in winemaking. If the vineyard is to be part of an existing farm, there is hopefully suitable land available within the farm. If land has to be bought, it is important to buy a sufficiently large area to cover future expansion of the vineyard. In our example we used the price of land in eastern Sweden, ${ }^{1}$ where farmland is very expensive compared with Australia. ${ }^{1,16}$

Following plantation, the vines must be pruned once a year followed by shoot thinning twice per year, which was estimated to take 4.4 minutes per vine, as suggested by the Agricultural Marketing Resource Center at Iowa State University (Table 1).${ }^{17}$ Attaching shoots and tendrils of each vine to wires is carried out once per season and was estimated to take 1 minute each vine. Tying-in vines is carried out once per season and was estimated to take 3 minutes per individual vine. Chemical crop protection was estimated to be carried out six times per season with a time requirement of 4 hours per ha at an hourly rate of $€ 38.0$ for labor and $€ 45.0$ per ha for chemicals. In our example, weed harrowing was calculated to be carried out four times per season for 4 hours per ha at an hourly rate of $€ 38.0$. Note, however, that the need for weed harrowing and spraying will vary with prevailing weather conditions and with climatic conditions, so the data used are estimated means. If the vines are grown in central Sweden, the disease and pest pressure will decrease considerably and this item can then be completely omitted.

When calculating equipment costs, some of the equipment required for cultivating vines is likely to be already present on a farm, eg, a tractor, but a new two-wheel drive tractor can cost from $€ 25,000$. However, most tillage implements have to be purchased since they are specialist equipment. The market for this type of equipment is small in Scandinavia, compared with southern and eastern Europe where it can be bought much more cheaply. Some machinery may be bought secondhand, but the secondhand market in Sweden is practically nonexistent. Once the vineyard and winery are established, continuous investments will be required in the form of upgrading equipment. In our example (Tables 1 and 2), depreciation on machinery was assumed to be $8.3 \%$ and interest was $3.5 \%$ of replacement value. Maintenance costs were estimated to be $€ 0.6$ per hour and $€ 100$ replacement value, based on replacement values for secondhand equipment. If completely new equipment is purchased, the costs can be considerably higher. Those interested in a comparative price example for a vineyard in Australia are advised to visit the Government of Queensland Website. ${ }^{16}$ A presentation of vineyard production costs in California has been made by the University of California cooperative extension ${ }^{18}$ and by Boehm. ${ }^{19}$ 
Wine production requires specialist equipment, which makes it expensive. Investments in good equipment of a quality appropriate to the operation must be made. The size/ capacity of the equipment chosen must reflect the initial needs of the vineyard, but must also meet the needs of any predicted expansion in at least the next 10 years. Wine production equipment includes stalk remover, cleaning table, press, fermenter, high-pressure washer, separator filter, yeast, vats, barrels, bottles, corks, labels, bottling equipment, a labeling machine, a steam machine for cleaning, pumps and measuring instruments, which were estimated in our example to have a total combined cost of $€ 100,000$. The size/ capacity of the chosen equipment has to meet the expected expansion of the business. The capacity requirement must be based on the capacity of the grape presses and the volume of the fermenter. If more than one variety of grapes is grown, the time between the planned harvests of these must be long enough to ensure that fermentation of the first lot is finished before the next lot needs the fermenter. The grape presses and fermenter volumes have a great impact on the size of the investment. In the example provided here, only one fermenter was used. This is a large investment and has to meet the requirements for at least 10 years. If more than one grape variety is grown, the time between harvests has to be long enough so the same equipment can be used for all grapes grown on the estate. In other cases, the equipment has to be duplicated, which doubles the investment costs. Capacity later in the production can be estimated in the form of time, which is more flexible. Whether it takes 1 day or 1 hour to put the labels on the bottles, for example, is not crucial for start-up vineyards, and therefore it could be recommended to not overinvest in equipment for the later stages of the production process.

To ensure a fermentation process with the desired outcome, it may be advisable to not rely on wild strains of yeast. The cost of yeast is difficult to estimate, since it can be purchased for less than $€ 1.0$, although yeast strains developed for cold climate wine production are much more expensive. Here, a decision should be made on whether to rely on more expensive, but probably more reliable, yeasts, tested to suit a colder climate. Using commercially available wine yeast strains gives greater predictability regarding how the flavor of the wine will develop. ${ }^{20-22}$ In the present calculation, a cost for the yeast of $€ 7500$ was used, covering a batch size from 500 to at least $5000 \mathrm{~L}$. Redrawing and mixing of wines from different vats, barrels, ages, etc in order to produce a wellrounded wine with the desired profile also demands labor and experience.
In our example, it was assumed that the cost of making 500 or $2000 \mathrm{~L}$ of wine was similar in terms of labor costs, which are independent of batch size. However, the costs of filters, bottles, corks, and labels are dependent on batch size and also add labor time. For clarification, large-scale filtering equipment is available on the market and is expensive to buy, but has low running costs. It was assumed that this type of equipment was unsuitable for the scale chosen here. A cork costs between $€ 0.3-1.4$, the middle of this range being regarded as suitable for this example. The bottle cost is strongly dependent on whether a standard bottle (EUapproved) or a designer bottle is used, while the same applies for the label. There is currently a lack of production capacity, at least for specialist bottles, which must be ordered at least a year in advance, increasing the capital requirement.

The cost of vats and barrels for storage and maturation depends on the strategy used. The cost of oak barrels in which to mature the wine is high, leading to the cost of the wine being affected by whether new casks or a mixture of new and old barrels are used. Barrels can be bought secondhand, since some vineyards only use them once.

Marketing and sale of the wine will demand time and expertise.$^{23,24}$ Here, the winegrower/maker must analyze the type of wine they wish to market and identify their target customer group. ${ }^{25}$ The trend is that consumers are trading up from lower quality wine to a higher quality and price segment, which will suit the Swedish producer. ${ }^{26}$ Wine produced in northern Europe has the advantage that the cold nights and the long hours of daylight give more aromatic grapes of a somewhat smaller size, which leads to a more concentrated grape must. Since the yield per unit area is low, the price of the Swedish-produced wines cannot compare in the standard market segment (Table 1). A high price can add to the image of the wine and be a good selling point if the wine can be branded as special in some way. ${ }^{27}$ Selling a bottle of wine that costs over $€ 10.0$ to a customer in Sweden is considered to be a question of selling an experience, not a beverage, given that the average price for a bottle of wine sold at Systembolaget is $€ 7$. The history surrounding the wine must be true to a great extent, and the wine has to be of high quality. Therefore, brand building is extremely important for success. The strategy for the vineyard, winery, and the final product has to be defined before starting. ${ }^{28}$ Resources and expertise for this have to be added to the team creating the vineyard and the wine.

The calculations presented here were based on own capital comprising $20 \%$ of the investment. It was calculated that the wine would be sold for a price to the wine producer of $€ 25$ 
(resulting in a retail price of $€ 33$ ). As shown, 1 year of lost harvest proved to be a disaster during the start-up period. For the case of $525 \mathrm{~L}$ per year (Table 1), note that profitability could not be achieved without an unrealistic price for the wine. For the case of $1050 \mathrm{~L}$ per year, it took 20 years to reach payoff, with a total investment of $€ 0.72$ million, and thereafter an yearly income in the range of $€ 0.07$ million could be achieved. For production of $1800 \mathrm{~L}$ per ha, which could be achieved in an established vineyard, the payoff time was 9 years and thereafter a yearly income of $€ 0.18$ million could be achieved. It can be concluded from the different scenarios shown in Tables 1 and 2 that annual wine production is the most important factor in achieving profitability, if the wine can be sold for the desired price.

\section{Conclusion}

Wine produced in northern Europe has the advantage that the cold nights and long hours of daylight give more aromatic grapes of a somewhat smaller size, leading to a more concentrated grape must. Since yield per unit area is low, the price of the Swedish-produced wines cannot compare in the standard market segment. A high price can be justified if an image has been built up around the wine and if the product is of high quality. Selling a wine that costs over $€ 10$ to a customer in Sweden is considered to be a question of selling an experience, not a beverage. The strategy of striving for a high-quality product must be defined before starting the vineyard and winery.

\section{Disclosure}

The author reports no conflicts of interest in this work.

\section{References}

1. Jordbruksstatistisk Arsbok 2012. Yearbook of Agricultural Statistics Including Food Statistics. [In Swedish, but with tables with Swedish and English text]. Örebro, Sweden: Statistiska Centralbyrån, SCB Tryck: 2009.

2. Beverland MB, Bretherson PB. The evolution of strategy in medium and large Auckland (New Zealand)-based wineries. J Wine Res. 1998;9: 43-54.

3. Tagliaube J. For Finland, the issue is selling its wine, not making it. The New York Times. 2008 June 29. Available from: http://www.nytimes. com/2008/06/29/world/europe/29baltic.html?_r=18c. Accessed June 24, 2013.

4. Dean R, Berwick F. We live in a marketing world-except in Europe. Aust New Zeal Wine Ind J. 2001;16:65-67.

5. Ferrer JC, Mac Cawley A, Maturana S, et al. An optimization approach for scheduling wine harvest operations. Intern J Prod Econ. 2008;112: 985-999.
6. Kostadinov G, Ivanov D, Peykov V. Methodical prerequisites for systemic analysis of technological variants for grape production. Bulg $J$ Agric Sci. 2008;14:341-347.

7. Maschmedt D, Fitzpatrick R, Cass A. Key for identifying categories of vineyard soils in Australia. CSIRO Land Water Tech Rep 30/02. Adelaide, Australia: CSIRO; Aug 2002.

8. Beverland MB. Shake-out! Will small wineries survive in the global wine trade? New Zeal Strat Managm. 1999;4:31-39.

9. Folwell RJ, Volanti M. The changing market structure of the USA wine industry. J Wine Res. 2003;14:25-30.

10. Jones GV, Storchmann K-H. Wine market prices and investment under uncertainty: an econometric model for Bordeaux Crus classes. Agric Econ. 2001;26:115-133.

11. Scott M, Bruce R. Five stages of growth in small business. Long Range Plan. 1987;20:45-52.

12. Gustafsson J-G, Mårtensson A. Potential for extending Scandinavian wine cultivation. Acta Agric Scand Sec B-S P. 2005;55:82-97.

13. SJFVS. SJVFS 2007:18. Statens jordbruksverks författningssamling. Jönköping, Sweden: Swedish Board of Agriculture; 2007. [In Swedish].

14. Rankine BC, Farnachon JCM, Boehm EW, et al. Influence of grape variety, climate and soil on grape composition and quality of table wines. Vitis. 1971;10:33-50.

15. Kostadinov G, Ivanov D, Peykov V. Effect of technological and regional conditions on costs in wine grape production. Bulg J Agric Sci. 2008;14:509-516.

16. Queensland Government. Establishing a vineyard or winery. Available from: http://www.business.qld.gov.au/industry/food/queensland-wineindustry/starting-a-wine-business. Accessed February 14, 2013.

17. University of Iowa State Agricultural Marketing Resource Center. Winery and Vineyard Feasibility Workbooks 2007. Available from http://www.agmrc.org/commodities_products/fruits/wine/winery_and_ vineyard_feasibility_workbooks.cfm. Accessed February 14, 2013.

18. University of California Cooperative Extension. 2001. Sample costs to establish a vineyard and produce wine grapes. Available from http://coststudies.ucdavis.edu/files/grapewinevn2001.pdf. Accessed February 14, 2013.

19. Boehm EW. Vineyard establishment-is there value in a vineyard. Tasm J Agric. 1976;47:242-243.

20. Bisson LF, Butzke CE. Technical enzymes for wine production. Agro Food Industry Hi-Tec. 1996;7:11-14.

21. Borneman AR, Chambers PJ, Pretorius IS. Yeast systems biology: modelling the winemaker's art. Trends Biotech. 2007;25:349-355.

22. Chambers PJ, Pretorius IS. Fermenting knowledge: the history of winemaking, science and yeast research. EMBO Rep. 2010;11:914-920.

23. Burton BJ, Jacobsen JP. The rate of return on investment in wine. Econ Injury. 2001;39:337-350.

24. Storchmann K. Wine economics: emergence, developments, topics. Agrekon. 2011;50:1-28.

25. Bouzdine-Chameeva T. How wine sector SMEs approach strategic questions - Some comparative lessons of casual representation of distinctive competencies. Br Food J. 2006;108:273-289.

26. Silverstein MJ, Fiske N. Luxury for the masse. Harvard Bus Rev. 2003;81:48-57.

27. Beverland MB. Uncovering 'theories-in-use': building luxury wine brands. Eur J Marketing. 2004;38:446-466.

28. Birley S. Corporate strategy and the small firm. In: Asch D, Bowman C, editors. Readings in Strategic Management. London: Macmillan; 1989:78-82. 
International Journal of Wine Research

Dovepress

\section{Publish your work in this journal}

The International Journal of Wine Research is an international, peer-reviewed open-access, online journal focusing on all scientific aspects of wine, including: vine growing; wine elaboration; human interaction with wine; and health aspects of wine. The journal provides an open access platform for the reporting

of evidence based studies on these topics. The manuscript management system is completely online and includes a very quick and fair peer-review system, which is all easy to use. Visit http://www.dovepress.com/testimonials.php to read real quotes from some of our published authors.

Submit your manuscript here: http://www.dovepress.com/international-journal-of-wine-research-journalisease-journal 